\title{
Heavy mineral studies of Gondwana sandstones of Eastern Arunachal Himalaya and implications for provenance
}

\author{
Bashab N. Mahanta ${ }^{1}$, Ranjan K. Sarmah ${ }^{1}$, Tapos Kumar Goswami ${ }^{1}$ and Banteilang R. Syngai ${ }^{2}$ \\ ${ }^{\mathrm{I}}$ Department of Applied Geology, Dibrugarh University, Dibrugarh 786004, Assam, India \\ ${ }^{2}$ Geological Survey of India, Shillong 793003, Meghalaya, India
}

\begin{abstract}
A thin linear belt of Permian Lower Gondwana rocks occur in the Eastern Himalayas from Arunachal Pradesh to Sikkim. The Lower Gondwana Group of rocks consists of shale, siltstone, sandstone, carbonaceous shale and coaly matter and is sandwiched between Miri Group and Siwalik Group of rocks. Heavy mineral composition of sandstones is extensively used in the provenance studies as they are the surviving remnants of the rather abundant but unstable mafic components of the source rock. The sandstones of Lower Gondwana Group bear the heavy mineral assemblage of chlorite, biotite, zircon, ilmenite, epidote, garnet, amphibole, chloritoid, brown tourmaline, magnetite, staurolite, rutile, and opaques which is indicative of a provenance of metamorphic rocks with input of igneous rocks. Provenance sensitive mineral index ratios were also calculated to see the variation in the ratio of two or more stable minerals with the same characteristics.
\end{abstract}

Received 17 October 2016 Accepted 20 March 2017

*For correspondence $\bowtie$ : bnmism@gmail.com

sciencevision@outlook.com

Key words: Heavy Minerals, Gondwana, Eastern Himalayas, Arunachal Pradesh.

\section{Introduction}

Heavy mineral composition of sandstones are widely used in the provenance studies in sedimentary petrology. These minor accessory minerals of sandstones are marked by a higher than average specific gravity and they are the surviving remnants of the rather abundant but unstable mafic components of the source rock. ${ }^{1}$ Over fifty different non-opaque heavy mineral species have been recognized in sandstones, many of which have specific parageneses that enable a direct match between sediment and source lithology. ${ }^{2}$ Heavy mineral assemblage is controlled by a number of factors such as nature of the parent rocks, vagaries of climatic conditions during weathering, relative solubility and stability of the various detrital minerals, their mineralogy, abrasion history, their density, size, sorting and past depositional changes experienced by the sediments. Because of their generally low abundance in sandstones and siliciclastic sediments, heavy minerals are usually concentrated for study by heavy liquid separation.

A linear belt of Permian Gondwana rocks occur in parts of Lesser Himalayan morphotectonic unit of Arunachal Pradesh. In Daring-Garu-Gensi area of eastern Arunachal Pradesh, the Bichom Formation equivalent to Lower Gondwana Group of rocks of Peninsular India is present and lies in 
direct contact with the Lower Siwalik Group (Dafla Formation). In this paper, an attempt has been made to study the heavy mineral assemblage of the rocks from the lower Gondwana rocks exposed in the West Siang District of Arunachal Pradesh to determine the provenance of the sediments.

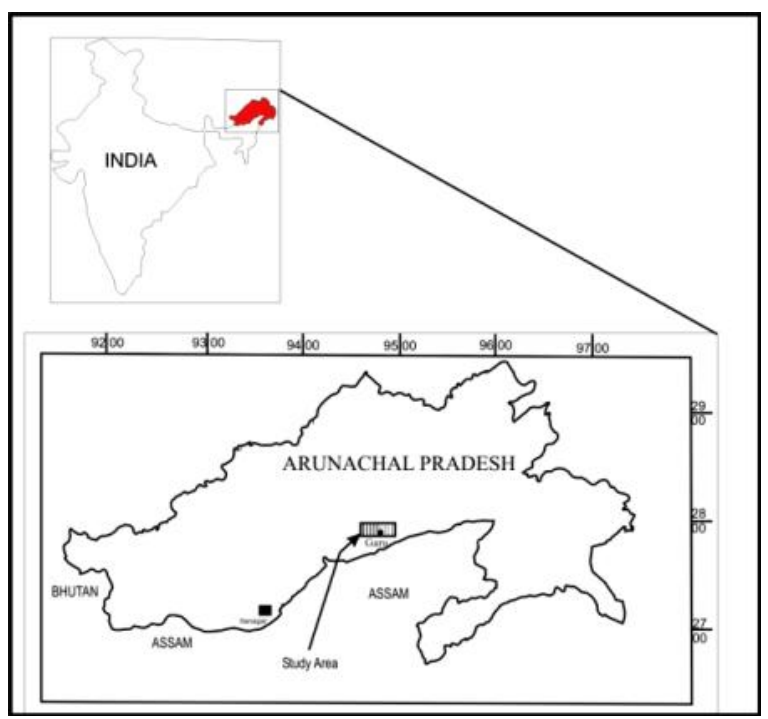

\section{Materials and Methods}

\section{Location and geological setting}

The Gondwana Group of rocks of the study area representing the northernmost rift system of Gondwanic India bear signatures of marine transgressions in Sakmarian times. The area under study is located in the districts of East Siang and West Siang of the state of Arunachal Pradesh (Fig. 1a). The north dipping Gondwana sequence is sandwiched between the Miri Group in the hanging wall of the Miri Thrust (MT) in the north and Lower Siwalik Dafla Formation in the footwall of the Main Boundary Thrust (MBT) in the south (Fig. 1b). The Bichom Formation represented by diamictite, orthoquartzite, khaki shale, grey shale, shaly coal, coal, carbonaceous shale, siltstone, sandstone, concretions with marine fossils. The sandstone is medium to coarse grained, thinly laminated and highly cross stratified at places. It is grey to reddish brown in colour. Carbonaceous streaks are distributed throughout the rock and this character varies

Figure 1a | Location map of the study area.

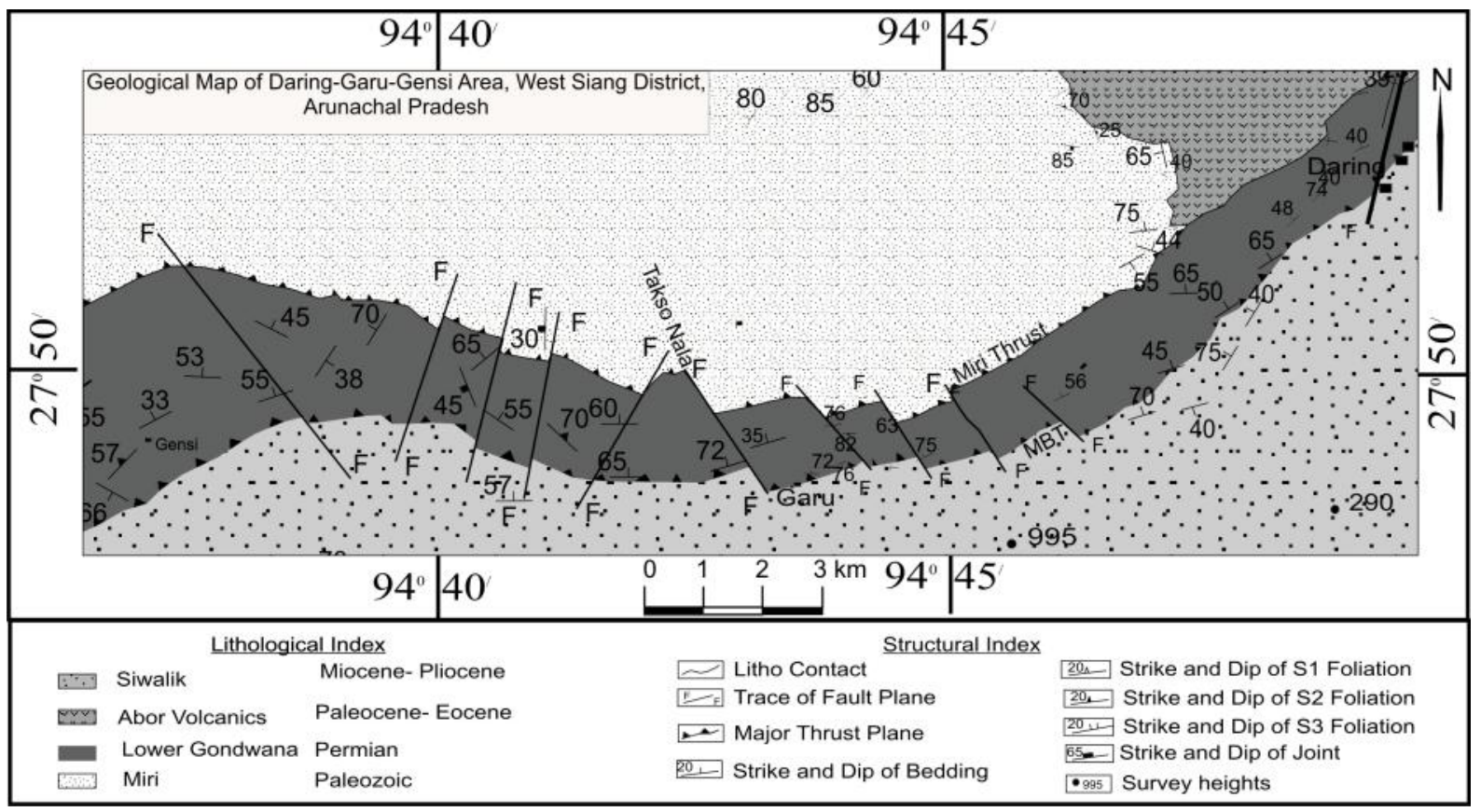

Figure 1 b | Geological map of Daring-Garu-Gensi area, West Siang District, Arunachal Pradesh. 
Table 1 | Geological setup of the studied area (modified after Kesari ${ }^{3}$ ).

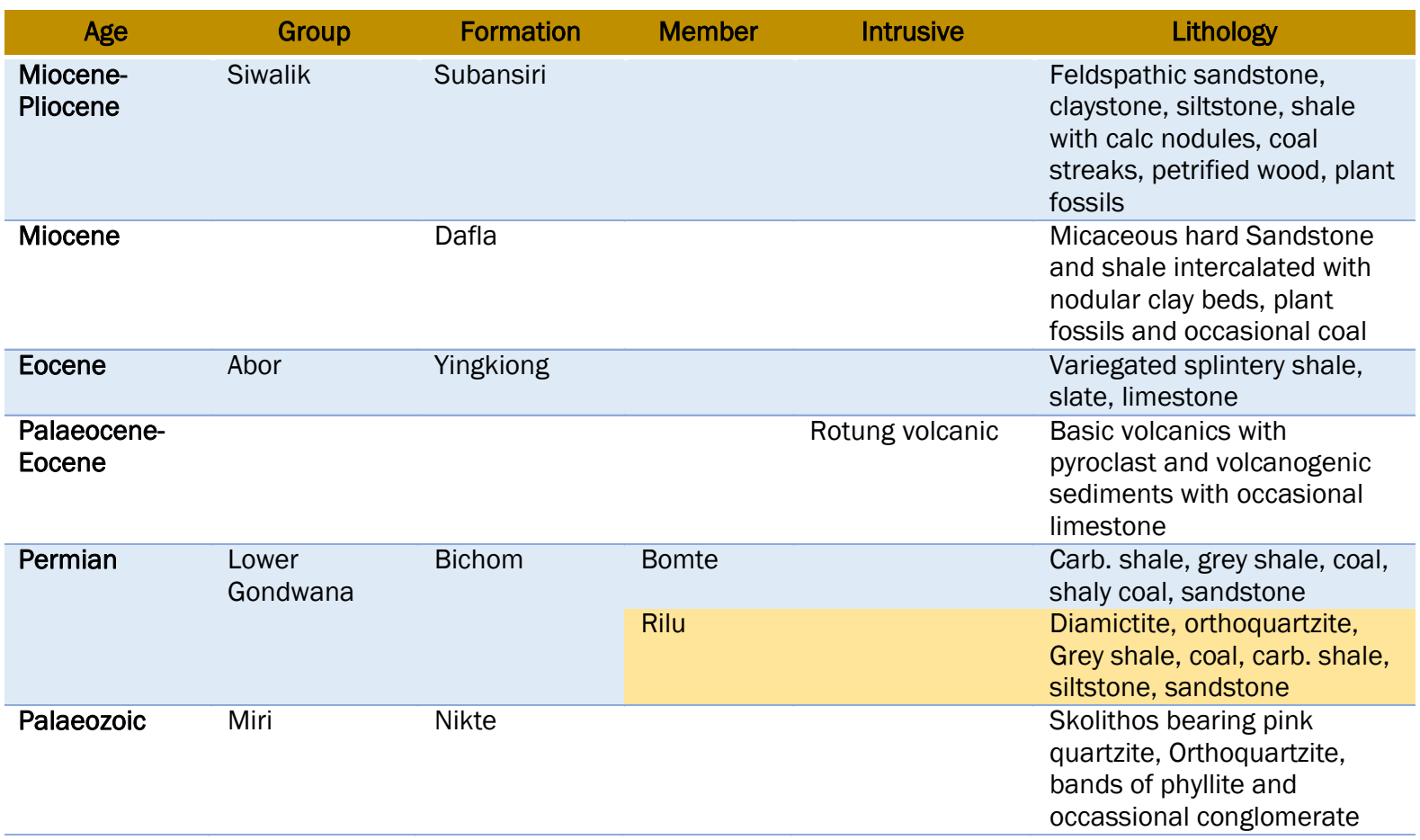

along the lateral continuity of the lithounit. Mica grains are aligned along the bedding planes. The general strike varies from NE-SW with moderate to steep dip towards north. At the proximity of the MBT, the current beddings are at high angle and mostly overturned. At places, the sandstone is massive and thick bedded having thickness up to 10 metres.

A tentative stratigraphic sequence of the area based on the principle of superposition of the lithounits and disposition of the primary and diastrophic structures modified after Kesari is summed up in Table $1 .^{3}$

\section{Analytical technique}

A total of 14 samples were collected and about $100 \mathrm{gm}$ of each of the samples was crushed to $(-80)$ mesh ASTM sieve size by rubber pestle and mortar. The crushed sample was reduced to about $20 \mathrm{gm}$ by coning and quartering.
The clay fraction of the samples was removed by repeated washing with water. The sand sized fraction was treated with mild acetic acid to eliminate carbonate and ferruginous coating. The samples were then boiled with distilled water and dried in an oven at low temperature. The cleaned and dried samples were put in a 150-ml conical separating funnel half filled with bromoform.

The separation of heavy minerals was carried out by gravity separation technique. The mixture was stirred at regular intervals for absolute separation of heavy and light fractions and heavy minerals were allowed to settle for 72 hours. The heavy fractions were removed on Whatman filter paper No. 4. These were washed with absolute alcohol and dried in an oven at low temperature. Heavy minerals thus separated from the samples were mounted on glass slides using Canada balsam for identification under the petrological microscope. 


\section{Results}

\section{Description of heavy minerals}

Heavy minerals identified from Gondwana sandstones consist of chlorite, biotite, zircon, ilmenite, epidote, garnet, amphibole, chloritoid, brown tourmaline, magnetite, staurolite, rutile, and rare chromite. The other notable phases are kyanite, siderite, chloritoids and apatite. The minerals unidentifiable under transmitted mode, i.e. ilmenite, magnetite, pyrite and chromite are grouped as opaques only.

The diagnostic characters of the heavy mineral assemblage of the sandstones are summarized below.

Chlorite: It constitutes $24.68 \%$ of the heavy mineral assemblage and occupies the first position in order of abundance in the Gondwana sandstones. The chlorite grains are sub-angular to sub-rounded in outline and shows micaceous habit. The cleavage flakes of chlorite exhibit pale green to pale brown colour (Fig. 2a)

Biotite: It constitutes $15.79 \%$ of the heavy mineral assemblage. The flaky biotite grains are pale-yellow to reddish-brown in colour (Fig. 2b).

Zircon: It constitutes $14.02 \%$ of the heavy mineral assemblage and occupies the third position in order of abundance. The grains are colorless to light pink, pyramidal and sub rounded to subangular. The grains are easily identifiable because of their high relief and high order of interference colour. Zoning is distinctly observed (Figs. 2c, d, e).

Ilmenite: It is the most dominant opaque mineral with an abundance of $11.52 \%$. Under reflected light, the sub-angular to sub-rounded opaque grains exhibit purplish-brown colour.

Tourmaline: Tourmaline constitutes $4.11 \%$ of the heavies. The grains are pleochroic, prismatic, pale-yellow to dark brown in colour. Dominantly the grains are angular, fractured and contains inclusions (Figs. 2f, g).

Kyanite: Kyanite occurs as colorless and elongated shape, cleavage is well developed. Shows inclined extinction. The percentage of kyanite is $4.13 \%$ (Figs. $2 h, i, j$ ).

Epidote: It constitutes $3.29 \%$ of the heavies. The grains show pale green to slightly grayish color. It also shows a moderately high relief, straight extinction and shows dark green to red interference color. The grains are sub-rounded, fractured and some occur as an irregular shape (Figs. 2k, l, m).

Garnet: Garnet constitutes $2.50 \%$ of the heavy mineral assemblage. The grains are colorless to pale brown in appearance and subangular to sub-rounded in outline. It contains inclusions and isotropic (Figs. 2n, o, p).

Staurolite: It constitutes $2.47 \%$ of the heavies. Staurolite grains exhibit various tints of golden yellow and brown colour and occur as sub-angular to sub-rounded grains (Fig. 2q).

Rutile: Deep reddish brown colour both in plain polarized light and under crossed nicols, shows straight extinction. It constitutes $1.65 \%$ of the heavy mineral assemblage of the Gondwana rocks (Figs. 2r, s).

Heavy minerals viz. apatite (1.77\%), chloritoid (1.65\%) (Figs. 2t, u), magnetitte (1.65\%), pyrite (0.90\%), amphibole (0.87\%), siderite (0.84\%) chromite $(0.82 \%)$ and opaques $(7.37 \%)$ were also identified from the Gondwana rocks.

Table 2 | Provenance sensitive mineral index ratios from Morton and Hallsworth ${ }^{2}$.

\begin{tabular}{lllc} 
Index & \multicolumn{1}{c}{ Mineral Pair } & \multicolumn{1}{c}{ Index Determination } & Observed values \\
ATi & Apatite, tourmaline & $100 \times$ apatite/(total apatite + tourmaline) & 28.57 \\
GZi & Garnet, zircon & $100 \times$ garnet/(total garnet + zircon) & 20.00 \\
RZi & $\mathrm{TiO}_{2}$ group, zircon & $100 \times \mathrm{TiO}_{2}$ group/(total TiO 2 group + zircon) & 60.00 \\
& & $100 \times$ chrome-spinel/(total chrome-spinel + zircon) & 7.69 \\
CZi & Chrome-spinel, zircon & $100 \times$ monazite/(total monazite + zircon) & 33.33 \\
MZi & Monazite, zircon & & 3
\end{tabular}




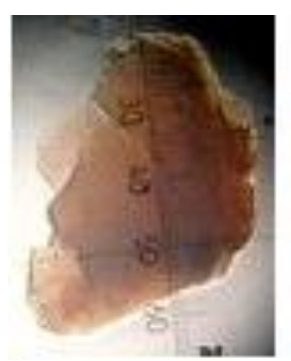

a

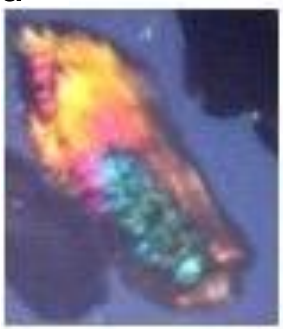

e

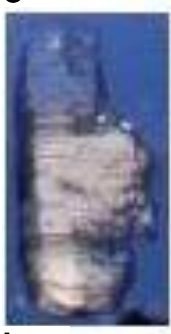

i

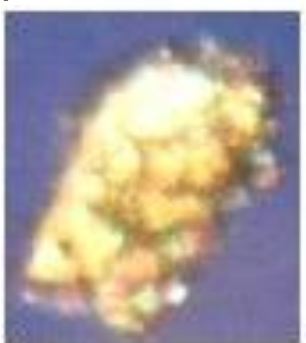

m

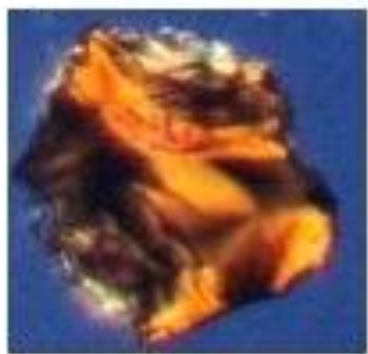

q

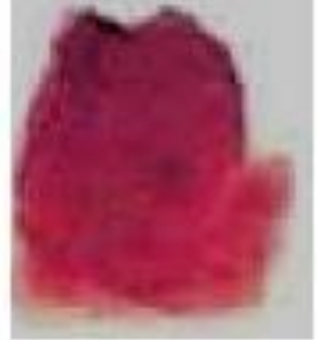

b

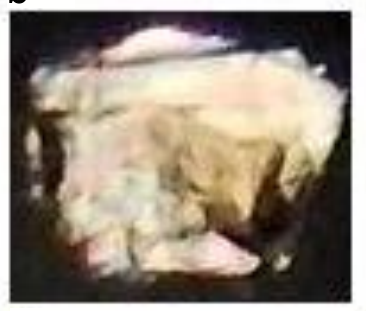

f

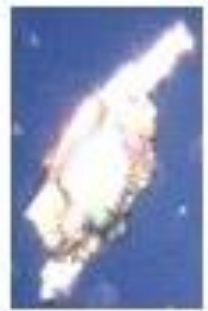

j

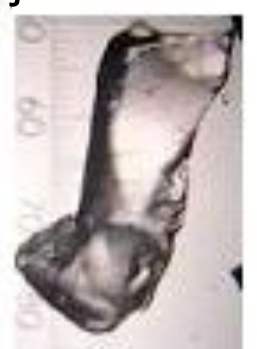

n

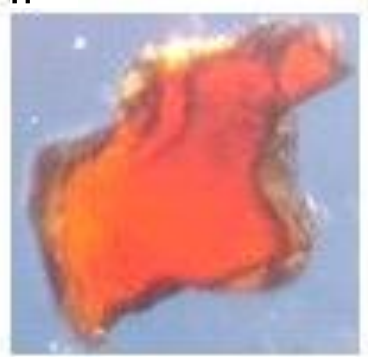

$r$

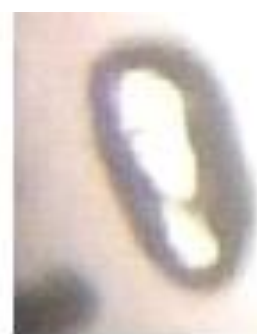

C

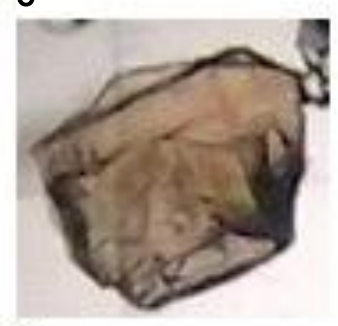

g

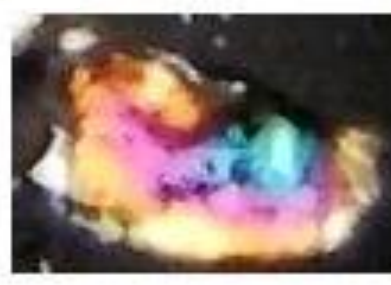

k

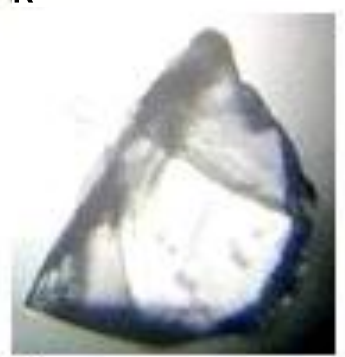

0

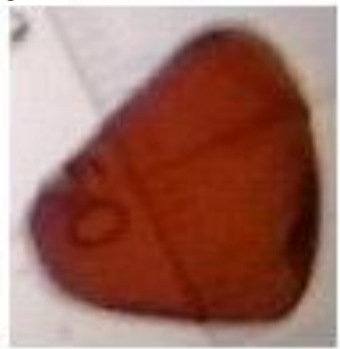

S

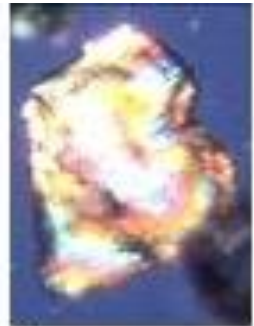

d

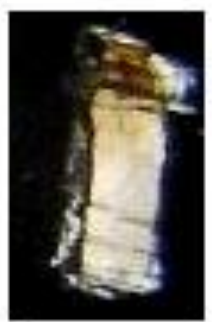

h

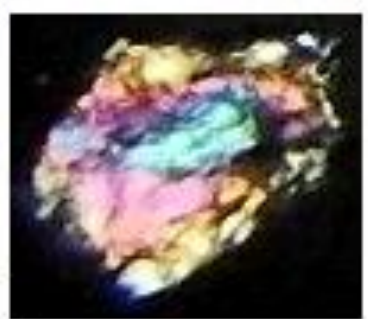

I

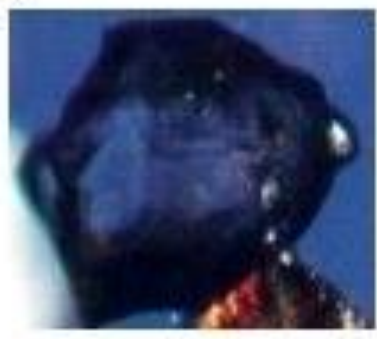

p

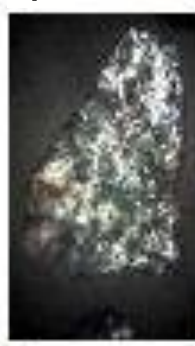

$t$

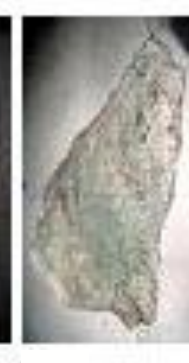

u

Figure $\mathbf{2}$ | Photomicrographs of heavy minerals of Gondwana sandstones, a, chlorite, b, biotite, $c-e$, zircon, $f, g$, tourmaline, h-j, kyanite, k-m, epidote, n-p, garnet, q, staurolite, r, s, rutile, t, u, chloritoid. 


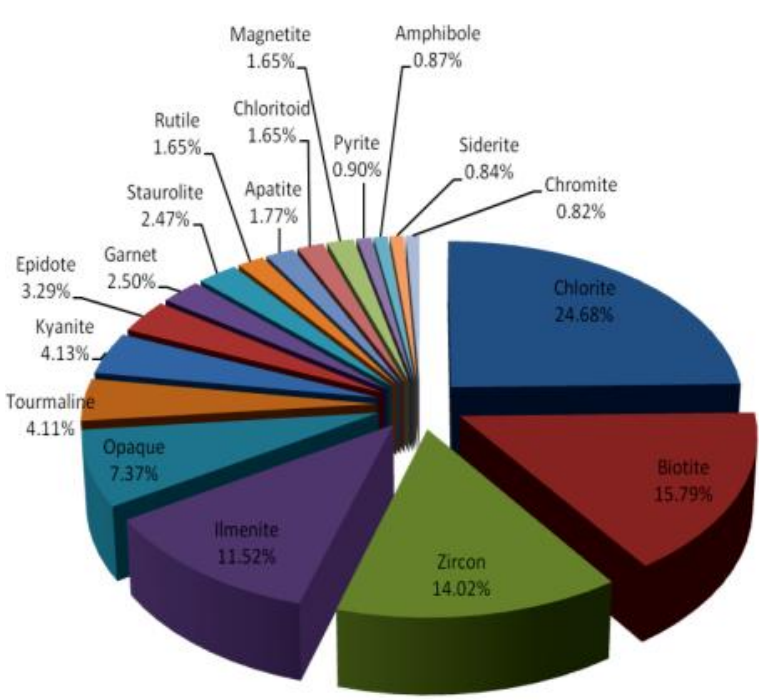

Figure 3 | Pie diagram of composition of heavy minerals in Gondwana sandstone.

\section{Provenance sensitive mineral index ratios}

Conventional heavy mineral data that most closely reflect the nature of the source area are ratios of stable minerals with similar hydraulic behavior. Variation in the ratio of two or more stable minerals with the same hydraulic behaviour (Table 2) corresponds to provenance change rather than mineral dissolution or hydraulic sorting. ${ }^{2}$ This approach gives a good characterisation of the entire mineral suites, the errors associated with the abundance of individual minerals are significant, particularly for minerals present in small amounts. Consequently, if mineral ratios are calculated using these data, the errors associated with each value is likely to be considerable.

\section{Discussion}

The heavy mineral suite of the Gondwana sandstone of the study area comprises a cosmopolitan mix. The assemblage comprising both unstable and stable minerals indicates their immature nature and little effect of intrastratal solutions. The assemblage is indicative of a provenance of acid igneous rocks and low to high grade metamorphic rocks. Relative dominance of chlorite (Fig. 3) indicates that during this phase of sedimentation, the gradient of the land surface was considerably high and the streams had higher velocity, as a result of which the detritus was transported and deposited quickly. ${ }^{4}$ The assemblage of rutile, tourmaline, zircon, garnet, apatite, chloritoid according to increasing stability indicates a deep burial diagenesis of the sandstones. ${ }^{5}$ Siderite might have been contributed by sedimentary rocks and a part of these may as well be of authigenic origin. ${ }^{6}$ Presence of zircon grains suggests their derivation from acid igneous rock. Epidote appears to have been derived from mesozone metamorphic rocks. Heinrich recorded that the assemblage biotite, chloritoid, epidote, tourmaline are derived from low and medium grade metamorphic parent rocks. ${ }^{7}$

From the ratios between related mineral pair (Table 2), the following inferences were made. Low ATi value (28.57) may indicate sub aerial exposure of the sediments in humid tropical climates, either as a result of deposition by fluvial systems, or by subsequent exposure at unconformities. ${ }^{2}$ It was observed that the GZi value (20.00) is lower indicating igneous rocks are the dominant source rock for the Gondwanas. RZi value (60.00) in Gondwana is higher indicating metapelite or granitoid sources. MZi value (33.33) is moderate which indicates that the metamorphic or sedimentary sources were more active than granites or granitic pegmatites in both the cases. Low CZi value (7.69) again indicates that there was less ultramafic contribution to both the basins.

The overall heavy mineral assemblages of the Lower Gondwana Group are suggestive of the fact that a major part of sediments were derived from metamorphic rocks with inputs from igneous rocks.

\section{Acknowledgements}

The authors are grateful to Ms. Bhaswati Baishya and Ms. Kakoli Banya Boruah for assistance in the laboratory works. 


\section{References}

I. Pettijhon FJ (1975). Sedimentary Rocks. CBS Publishers and Distributors, Delhi, pp487.

2. Morton AC \& C Hallsworth (1994). Identifying provenance-specific features of detrital heavy mineral assemblages in sandstones. J Sed Geol, 90, 24I-256.

3. Kesari GK (20I0). Geology and Mineral Resources of Arunachal Pradesh. Geol Surv India, Misc Pub, 30, IV I (i), Arunachal Pradesh.

4. Hota RN \& W Maejima (2009). Heavy minerals of the
Barakar Formation, Talchir Gondwana Basin, Orissa. J Geol Soc India, 74, 375-384.

5. Morton AC (1985). Heavy minerals in provenance studies. In: Provenance of Arenites (G.G. Zuffa, ed), D. Reidel Publishing Company.

6. Singh M (20I2). Heavy mineral assemblage of the Pinjor Formation of the Northwestern Himalaya and its significance in deciphering the provenance of the sediments. Geosciences, 2 (6), I57-163.

7. Heinrich EWM (1956). Microscopic Petrography. McGraw Hill Book Co., Inc., New York, p. 444. 